\title{
DEVELOPMENT AND TESTING OF NOVEL FERROCEMENT WALL
} PANELS

\author{
K. N. Lakshmikandhan ${ }^{1}$, P. Sivakumar ${ }^{2}$, R. Ravichandran $^{3}$, K. Sivasubramanian ${ }^{4}$, S.Saibabu ${ }^{5}$ \\ ${ }^{1}$ Scientist, CSIR-Structural Engineering Research Centre, Chennai, India \\ ${ }^{2}$ Scientist, CSIR-Structural Engineering Research Centre, Chennai, India \\ ${ }^{3}$ Scientist, CSIR-Structural Engineering Research Centre, Chennai, India \\ ${ }^{4}$ Scientist, CSIR-Structural Engineering Research Centre, Chennai, India \\ ${ }^{5}$ Scientist, CSIR-Structural Engineering Research Centre, Chennai, India
}

\begin{abstract}
The population growth and urbanization have resulted in demand for shelters and construction materials. There is equal challenge to develop new techniques and technologies to cope up with the demand. Further the natural and manmade disasters are the huge threat in current scenario which needs development of structural components or system to manage the post disaster requirements such as speedy and mass construction of buildings. The advancement in research made wider alternatives with many options to overcome these demands. In view of this, the present investigation aims at developing affordable technologies, particularly for the rural and poor urban population. The novel light weight ferrocement wall panel with required stiffness and strength is investigated. This technology reduces the usage of conventional building materials and overall structural weight and cost. The wall panel is proposed with ferrocement skin with appropriate ribs to achieve the structural adequacy and constructability. The analytical parametric study is carried out using the nonlinear finite element analysis. The material nonlinearity is modeled using damaged plasticity model. The ferrocement panels of various sizes with window opening and with door opening are examined. The analytical study showed that the ferrocement panel with proposed ribs performs well. Further a $25 \mathrm{~mm}$ thick ferrocement wall panel with $1 \mathrm{~m}$ width and $2 \mathrm{~m}$ height is experimentally investigated and the results were compared. The conventional method of precasting of ferrocement panel is long, tedious and labour intensive construction methods in practice. To make it simple and cost effective, the single vertical casting is proposed using self-compacting concrete. Several mix trails were carried out and the suitable mix is obtained. The supporting systems and mould were developed to cast the wall panel within a few minutes. The panel is found to be more uniform and better quality. The panel is tested for in-plane compression loading. The strain and deflections were measured and plotted for comparison. Both the analytical and experimental results are found comparable. The present study found that the novel ferrocement wall panel is more appropriate for the light weight and affordable building construction.
\end{abstract}

Keywords: Ferrocement, Light Weight, Wall Panels, Non-linear, FEM, in-plane loading, Experimental testing $* * *$

\section{INTRODUCTION}

Cost effective housing is a relative concept that seeks to reduce construction cost through effective utilization of locally available building materials along with improved skills and technologies without sacrificing the strength, safety, performance and life of the structure ${ }^{1-4}$. In order to build a large number of buildings in a short time, prefabrication is the choice of engineers to precast the structural components at low cost with higher quality control. Precast concrete is a construction method, produces the products at controlled environment. Ferrocement is the solution to reduce the weight without compromising the performance ${ }^{5}$. Ferrocement was invented by Lambot in 1848. Ferrocement is a composite material comprising rich cement mortar reinforced with closely spaced small diameter steel rods and wires. In the construction of costeffective structures, thin elements were used to produce structural members such as folded plates, flanged beams, wall panels etc. For low cost housing thin ferrocement panels were used in floor construction due to its low cost and good structural performance. In terms of structural behavior it exhibits very high tensile strength-to-weight ratio and superior crack resistant performance ${ }^{4}$. But, the methods of ferrocement construction in practice are plastering and shotcreting time consuming and labor intensive. The literature review clearly shows that the implementation of thin elements with effective use material alternatives can reduce the cost without compromising the strength.

In view of above, it is vital to investigate the behaviour of ferrocement wall panels with the advancements in present construction scenario. The analytical tools are more advantageous in predicting the behaviour. The present investigation proposed to assess the overall structural response of panel with ultimate load, load-deflection characteristics and strain distribution characteristics. A nonlinear finite element analysis is carried out to predict the structural behaviour of different ferrocement panel systems. The panel is investigated with a thickness of $25 \mathrm{~mm}$ and projecting rib thickness of $50 \mathrm{~mm}$ (excluding panel thickness). The width of projecting ribs is $75 \mathrm{~mm}$. The panel 
has longitudinal bars and stirrups of $6 \mathrm{~mm}$ diameter in the projecting ribs. The spacing of stirrups is $250 \mathrm{~mm} \mathrm{c} / \mathrm{c}$. The clear cover to reinforcement is adopted as $15 \mathrm{~mm}$. The panel has welded wire mesh square in shape at the centre of $25 \mathrm{~mm}$ thick wall which laps over the reinforcement ring. The wire mesh is $2 \mathrm{~mm}$ in diameter and at a spacing of $35 \mathrm{~mm} \mathrm{c} / \mathrm{c}$. The size of hollow portion of panel is $850 \mathrm{~mm} \times 887.5 \mathrm{~mm}$. Material nonlinearity is considered in the analysis for both concrete and steel to obtain the numerical solution with higher accuracy. Further, the present study aimed to develop the construction method for precast wall panels of different sizes using the advancements in self compacting mortar with vertical casting of ferrocement panel in a single casting.

\section{ANALYTICAL INVESTIGATION}

Panels of various sizes were examined with the standard finite element software ABAQUS. Panel modelling is made with seven parts including concrete panel, steel bars horizontal, steel bars vertical, stirrups horizontal, stirrups vertical, wire mesh long, wire mesh short as per requirement in size and length. Parts were created, meshed with 8 noded linear hexahedron elements (C3D8R), assigned material properties and taken into assembly section. The concrete / steel parts were separately joined by tie constrain as shown in Fig. 1 and then steel cage was placed inside the concrete and assigned embedded constrain. The material properties were assigned to all the parts of concrete and steel. The concrete is modelled with damaged plasticity model and steel is modelled with plasticity model. The density of concrete is taken as $24 \mathrm{KN} / \mathrm{m}^{3}$ and the Young's modulus is taken as $25000 \mathrm{~N} / \mathrm{mm} 2$ With Poisson ratio of 0.18 . The tensile cracking and a compressive crushing are the main failure mechanisms of the concrete in the concrete damaged plasticity model. The model considers the degradation of the elastic stiffness induced by plastic straining both in tension and compression. The stress strain behaviour of concrete in compression is taken from the test results of cylinders of proposed concrete mix. The mechanical properties of proposed self compacting concrete is shown in Table1 and the typical view of load deflection curve which obtained from the CTM and the modified stress strain curve are shown in Fig. 2. The plasticity of model also considers 35 degree for dilation angle and 1.16 for the ratio between equibiaxial compressive stresses to uniaxial compressive stress. The ratio of the second stress invariant on the tensile meridian to that on the compressive meridian, $\mathrm{K}$ is taken as 0.667. The tension stiffening option is used to define the concrete's post failure behavior. The tension behavior of concrete is included as in terms of yield stress with 0 plastic strain and failures stress of 0 with cracking strain which is greater than 10 times of elastic strain of concrete. Plasticity of steel is taken from the IS 800, Indian code of practice for general design consideration for steel. The Static Riks method of structural analysis is carried out and the ultimate load is calculated by multiplying the applied load with the maximum LPF from the history output.

\section{EXPERIMENTAL INVESTIGATION}

The ferrocement panel of $2 \mathrm{~m}$ height and $1 \mathrm{~m}$ width is chosen to investigate its performance experimentally. The typical view of panel is of size $1 \mathrm{~m} \times 2 \mathrm{~m}$ as shown in Fig. 3. The panel has a wall thickness of $25 \mathrm{~mm}$ and projecting rib thickness of $50 \mathrm{~mm}$ (excluding panel thickness). The width of projecting ribs is $75 \mathrm{~mm}$. The size of hollow portion of panel is $850 \mathrm{~mm} \times 887.5 \mathrm{~mm}$. The panel has longitudinal bars and stirrups of $6 \mathrm{~mm}$ diameter in the projecting ribs. The spacing of stirrups is $250 \mathrm{~mm} \mathrm{c} / \mathrm{c}$. The clear cover to reinforcement is adopted as $15 \mathrm{~mm}$. The panel has welded wire mesh square in shape at the centre of $25 \mathrm{~mm}$ thick wall which laps over the reinforcement ring. The wire mesh is 2 $\mathrm{mm}$ in diameter and at a spacing of $35 \mathrm{~mm} \mathrm{c} / \mathrm{c}$. The wire mesh lies at the centre of $25 \mathrm{~mm}$ panel.

The ferrocement elements are fabricated with highly skilled labours. It is more complicated or rare possible due to lack in quality masons. To overcome these problems, it is proposed for single vertical casting with SCC. The supporting system and mould are the important components to withstand the flowable concrete pressure in lateral direction. In order to counteract this lateral pressure, formwork has been designed using STADD Pro. The configuration of supporting truss is chosen as Pratt. The truss has been designed for $3 \mathrm{~m}$ height with diagonal and cross bracings. Further plywood mould has been made with two numbers of hollow boxes with internal stiffeners. After the fabrication of plywood mould, the reinforcements were placed in position. Then wire mesh was tied with the reinforcement cage.

\subsection{Development of Self Compacting Concrete}

Specific gravity test and fineness modulus test were carried out to ascertain the material properties. Fineness modulus test was carried out with the following IS sieves $10 \mathrm{~mm}$, $4.75 \mathrm{~mm}, 2.36 \mathrm{~mm}, 1.18 \mathrm{~mm}, 600$ microns, 300 microns and 150 microns. The SCC/SCM properties were chosen based on its rheological charecteristics of concrete. The mix ratio for self compacting mortar has been arrived based on trial and error. The flow chrecteristics of concrete is examined with the help of flow table, $\mathrm{V}$ funnel test and cone test as shown in Fig. 4. Based on the rheological characteristics of trail mixes, the results were observed and presented in Table. 2. The mix proportion for self compacting mortar was arrived based on trial and error. From the trail mix results, the trail mix TM-7 is found suitable for casting the ferrocement wall panel in vertical position. In the mix TM7, the average slump diameter of SCM was found to be $700 \mathrm{~mm}$. The average flow time of SCM in V-funnel was found to be 4.23 seconds. The density of SCM was found to be $21.582 \mathrm{KN} / \mathrm{m}^{3}$. The mix was found to be cohesive without segregation and bleeding and this mix was chosen for vertical casting. The self-compacting mortar was prepared and poured from the top of the mould as shown in Fig. 5a. The specimen was demoulded on the next day of casting and is being cured by covering with wet gunny bags for $28^{\text {th }}$ days as shown in Fig. 5 b. 


\subsection{Testing of Ferrocement Wall Panel}

The ferrocement panel was shifted from the casting yard and prepared for testing. The panel was white washed and dried. The grid lines were marked on the panel. The panel is positioned at the test floor. A 200 Tonnes hydraulic jack was mounted on the loading frame and the gap between the floor, panel and jack ware filled with suitable steel sections and a 100 Tonnes capacity load cell are positioned as shown in Fig. $6 a$ and $6 \mathrm{~b}$. The level of loading setup and panel was checked using spirit level and ensured the both vertical and horizontal levels before testing. Arrangements have been made to prevent the toppling of panel by providing supporting angles and channels. Four numbers of electronic dial gauges were placed to measure the deflection of panel. First dial was placed below the top rib of panel. Second dial was placed above the middle rib of panel. Third and fourth dial were placed each at the centre of hollow portion of panel. First and second dial were used to measure panel's vertical displacement and the third and fourth dials were used to measure the longitudinal buckling of panel. Also strain gauges were used to measure the deformation in the panel at five different locations. First strain gauge was placed below the top rib. Second and third strain gauges were placed at the side ribs at $0.5 \mathrm{~m}$ and $1.5 \mathrm{~m}$ height. Fourth and fifth strain gauges were placed at the plane face of panel at $0.5 \mathrm{~m}$ and $1.5 \mathrm{~m}$ height. The typical view of strain gauge locations (designated ST) and dial gauge locations (designated D) were shown in Fig. 6c. The strain gauge, dial gauge and load cell were connected to data logger for retrieval of results. Load was applied gradually using hydraulic jack (ENERPAC) and the response of panel was recorded for the comparison.

\section{RESULTS AND DISCUSSION}

The analytical investigation was carried out on different wall panel configuration and the results were observed in terms of displacement at different panel locations and the maximum and minimum principle strains and stresses. The displace contours and strain contours obtained from the analysis for the different configuration of wall panels are shown in Fig. 7.

For all the panels A, B, C, D, F, G and H, the maximum displacement occurs at the top horizontal rib of panel. In these panel top ribs, the vertical displacement is higher on the open side. This indicates higher straining in the nearby location of top rib. The load deflection comparisons of different panel systems were presented in Fig. 8.

The strain is uniform in panel A and it occurs just below the top horizontal rib. For the panel B, the strain is very high at just below the top horizontal rib. For panel C, moderate strain occurs at the vertical ribs of bottom $1 \mathrm{~m}$ and mild strain occurs at the vertical ribs of top $1 \mathrm{~m}$. For panel, D greater strain occurs just below the top horizontal rib and moderate strain occurs at the middle vertical rib of top $1 \mathrm{~m}$. For panel E, mild strain occurs just above the bottom horizontal rib and moderate strain occurs in the vertical ribs of bottom $1 \mathrm{~m}$. For the panel F, mild strain occurs at the top most inner vertical ribs. For the panel $G$, higher strain occurs just below the top horizontal rib excluding the middle portion.

The panel-A was tested experimentally to verify the analysis results of panel-A. The panel was tested by increasing the load and corresponding response of panel was recorded. The load was increased gradually and there is a load drop was observed when the load reaches at $230 \mathrm{kN}$. The first crack appeared at the junction of top rib to the ferrocement panel. Further the load was increased and several cracks were observed below the top ring beam and the ferrocement panelas shown in Fig. 9 and this cracks similar to the strain contour obtained from the analysis in the form of maximum principle strain which is shown in Fig. 7.

Some diagonal cracks were observed in the top hollow portion of panel. Significant buckling was observed in the hollow portion of panel. Centre of Panel in the inside the four top ribs displaced more than the bottom panel centre. The load and displacement comparison of different location of panel are shown in Fig. 10. The displacement pattern represents the performance of panel in combined bending and compression. The dial gauge fixed at the centre of top centre portion of panel moves in the same direction of lateral direction. But the dial gauge fixed in the centre of bottom panel portion indicates the lateral movement in the one direction and it reversed in to opposite lateral direction, which is due to the buckling of panel. The dial gauge readings of D3 and D4 clearly indicate the slender column like behaviour (Cantilever $\mathrm{I}^{\text {st }}$ mode). Further the edge beam stiffness makes the panel to buckle laterally, which is seen in the deflected pattern at D4.

The strain gauge reading is recorded in the data logger. The maximum ultimate load is found as $460 \mathrm{kN}$ which is represents the axial compression stress of $7.67 \mathrm{~N} / \mathrm{mm}^{2}$. The stress clearly indicates its suitability for the infill wall applications. Further, the panel failure is not sudden and it keeps on carries the load. For instance, the panel carries the load of 40 Tonnes and the vertical deflection is around two times of the deflection recorded at the ultimate load. The strains recorded at the various locations are compared in Fig. 11a and 11c.

The panel was initially in compression in the entire volume and in later the vertical ribs were in compression and the other locations were keep on changing its stressing nature. The strain under the top rib was in compression and it become tension and fails at the ultimate load as shown in Fig. 11b. The thin wall of wall panel was in keep on change in the strain readings. The top and bottom centre of panel skins were in compression initially and become compression for a while. Later the strain in the top panel skin is become compression and the bottom panel skin is in tension. The reversed strain readings were seen in the top and bottom skins until the failure occur. The recorded strain variations in ST3 and ST4 are mainly due to the buckling of panel. The strain records clearly imitate the behaviour like long columns. Further the wall panel keeps on perform better 
even after reaching the ultimate load and it ensures the ductile behaviour of wall panel.

The ultimate load capacity of panels A, B, C, D, E, F, G and $\mathrm{H}$ from load displacement curve (LD curve) are presented in Table 3 for the comparison. Also weight analysis has been performed to compare conventional masonry wall, ferrocement wall panel without ribs and with ribs for a size of $1 \mathrm{~m} \times 2 \mathrm{~m}$. The weight analysis is presented in Table 4 .

It has been observed that the weight reduction on using ferrocement wall panel without ribs and with ribs are 87.414 $\%$ and $81.2314 \%$ respectively. The reduction in the wall dead weight has major influence on the reduction in structural total weight without compromising the wall strength. The overall weight reduction results in reduced structural design section of beams, columns and foundation which is being the key factor for affordable and cost effective buildings. The ribbed ferrocement panels are having higher strength to weight ratio.

\section{CONCLUSION}

The following conclusions were arrived from the analytical and experimental investigation of wall panels for the better understanding

1. Ferro cement structures are very light in weight compared to the brick infill walls. The ferrocement wall panels are sufficiently stronger compared to the conventional brick walls.

2. The Ferrocement wall panels are exhibited more ductile behaviour. After reaching the ultimate load, the failure mode is not sudden and it deforms more with minimum changes in the load carrying capacity, which indicates its energy dissipating capacity.

3. The aspect ratio of panel has influence on the displacement contour, strain contour and load carrying capacity

4. The opening for window and door has more influence on the strength and the openings reduce the strength and increase the deflection, which requires additional attention during the design.

5. The analytical and experimental result has about $45 \%$ difference, which requires further improvement in the model. Further the difference is the possibility due to the strength characteristic variation of concretes due to its anisotropic material Characteristics, which requires further modification in the material model.

\section{ACKNOWLEDGEMENTS}

This work has been carried out as a part of CSIR-800 Program. This paper is being published with the permission of Director, CSIR-SERC.

\section{REFERENCES}

[1] Lakshmikandhan, K.N., "Experimental and evaluation study on ferrocement infilled RC framed structures", Proc. of Int. Conference on recent advances in concrete and construction technology, 79 December 2005, SRMIST, Chennai, India. pp 833843.

[2] Vivian, W, "Cost effectiveness of using low cost housing technologies in construction", Procedia Engineering, V. 14, No. 2, 2011, pp. 156-160.

[3] Cheah, A., Ramli, S., "Load capacity and crack development characteristics of HCWA- DSF high strength mortar ferrocement panel in flexure", Construction and Building Materials, V. 36, No. 2, 2012, pp. 348-357.

[4] Grija, S., Sivakumar, P., Lakshmikandhan, K.N., Ravichandran, R., Karthikeyan, B., "Novel Ferrocement Light Weight Wall Panels", International Journal of Applied Engineering Research, V. 9, No. 18, 2014, pp. 4645-4657.

[5] Waleed, A., Yavuz, Y., Jaafar, M.S., Noorzaei, J., "Structural behaviour of ferrocement- brick composite floor slab panel", Construction and Building Materials, V. 24, No. 6, 2010, pp. 22242230. 

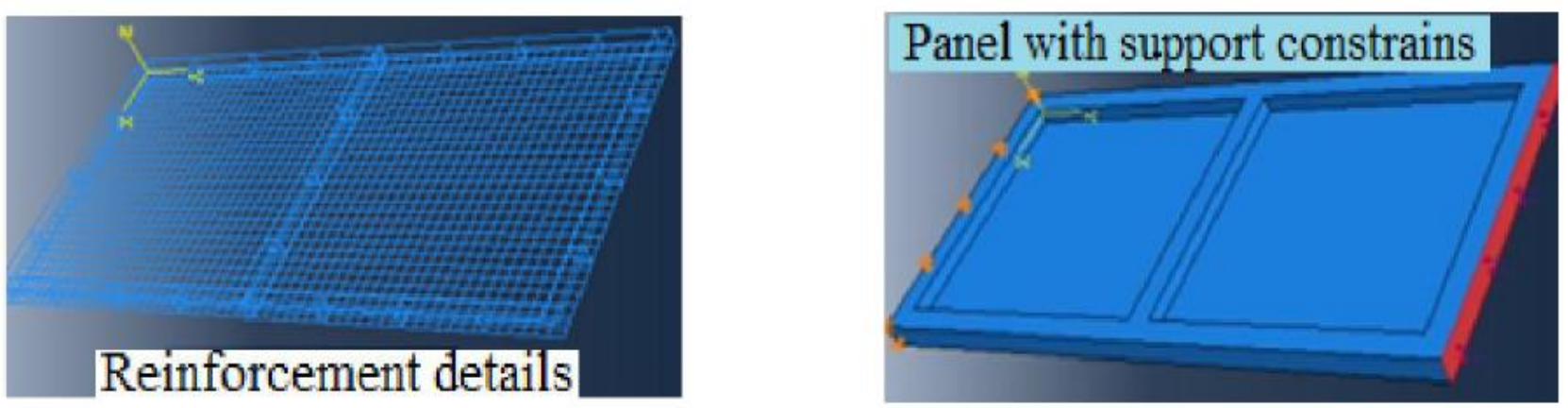

Fig 1. Typical view of Ferrocement panel model with loading and support constrains

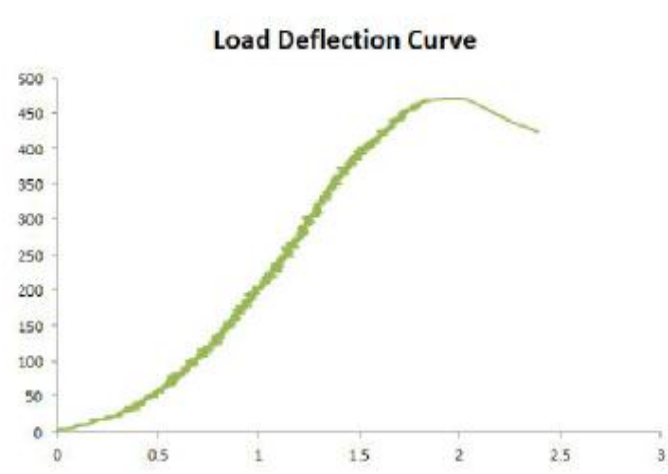

(a) Load deflection curve

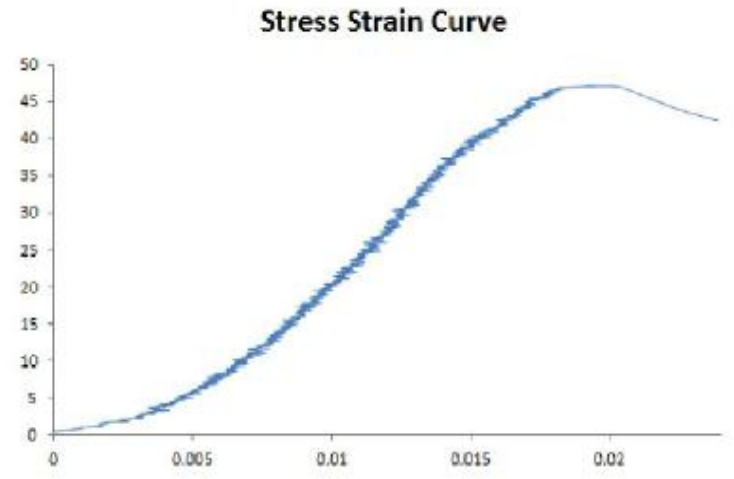

(b) Stress-strain curve

Fig 2 Typical load deflection and stress strain curve of cube

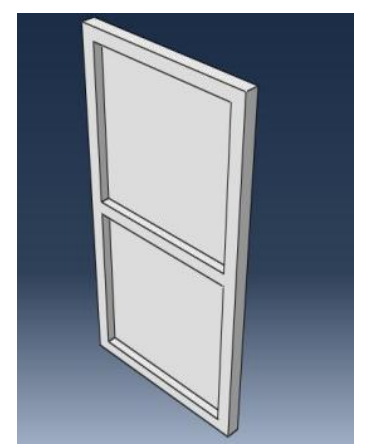

Fig 3 Typical view of ferrocement wall panel
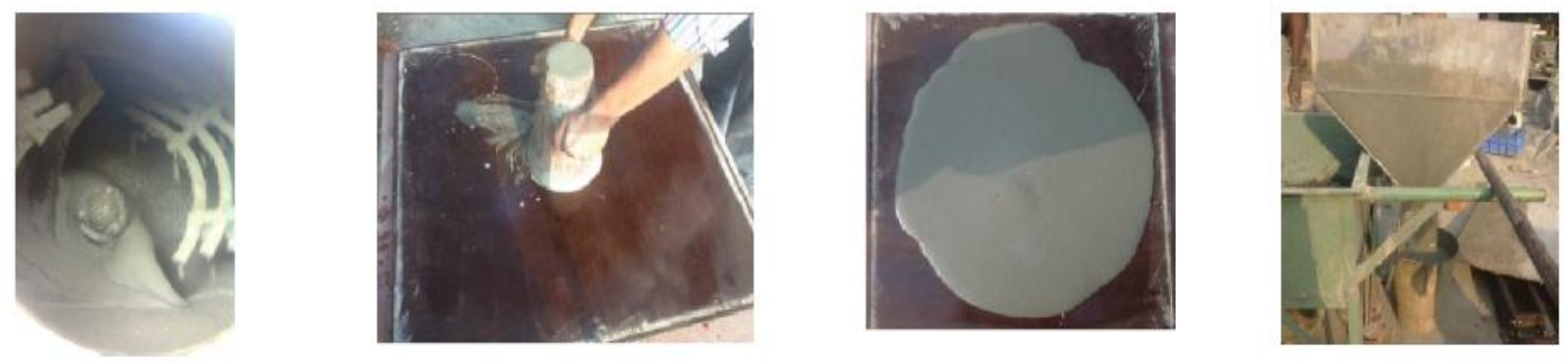

Fig 4 Rheological characteristics of SCM 


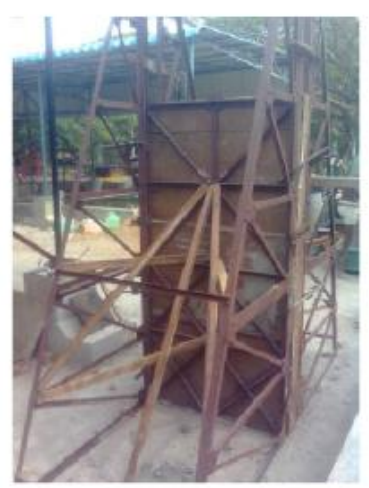

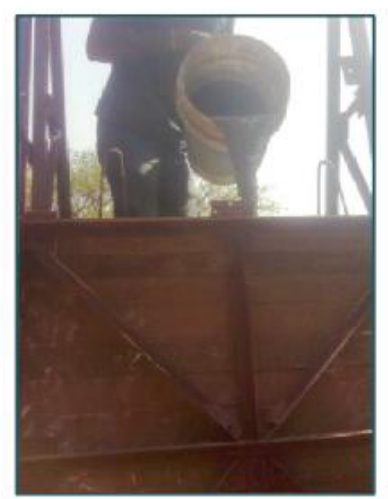

(a) Supporting system and single vertical casting of panel

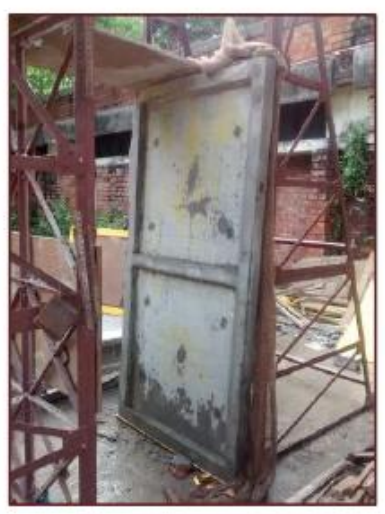

(b) Curing of specimen

Fig. 5 Casting of the wall panel
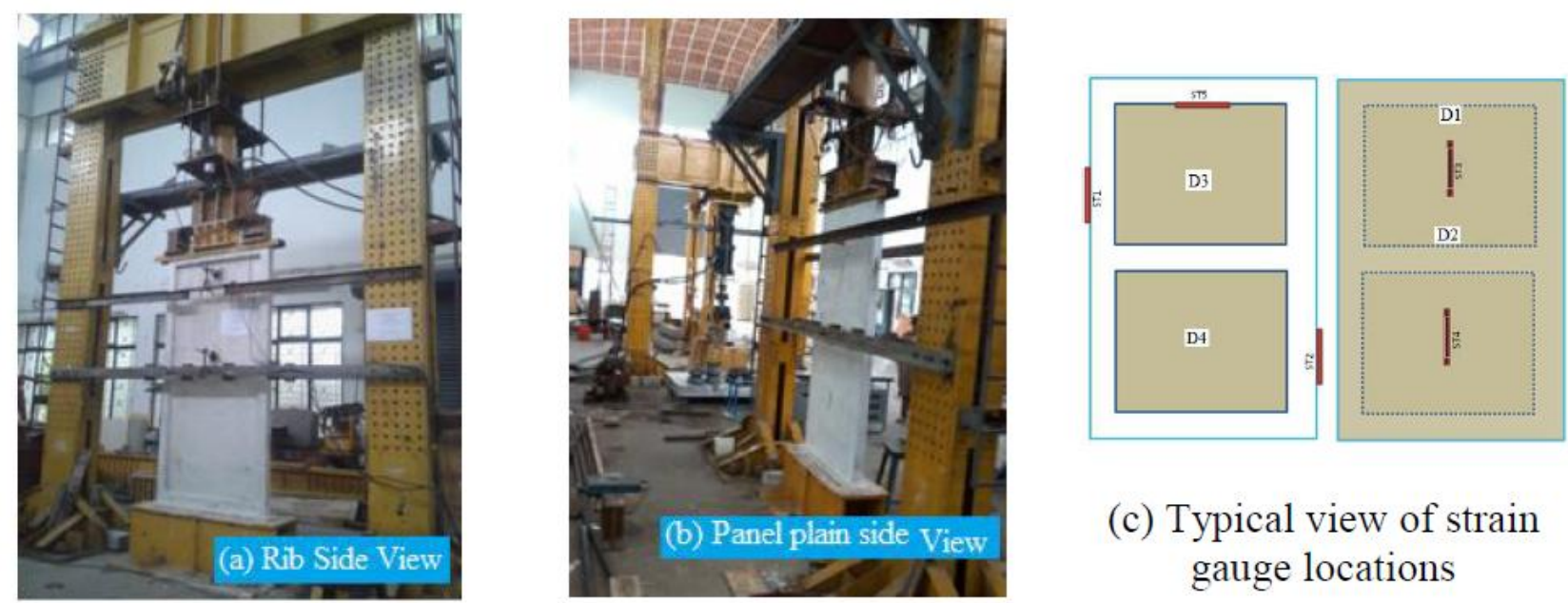

(c) Typical view of strain gauge locations

Fig 6. Typical view of Testing of ferrocement panel 


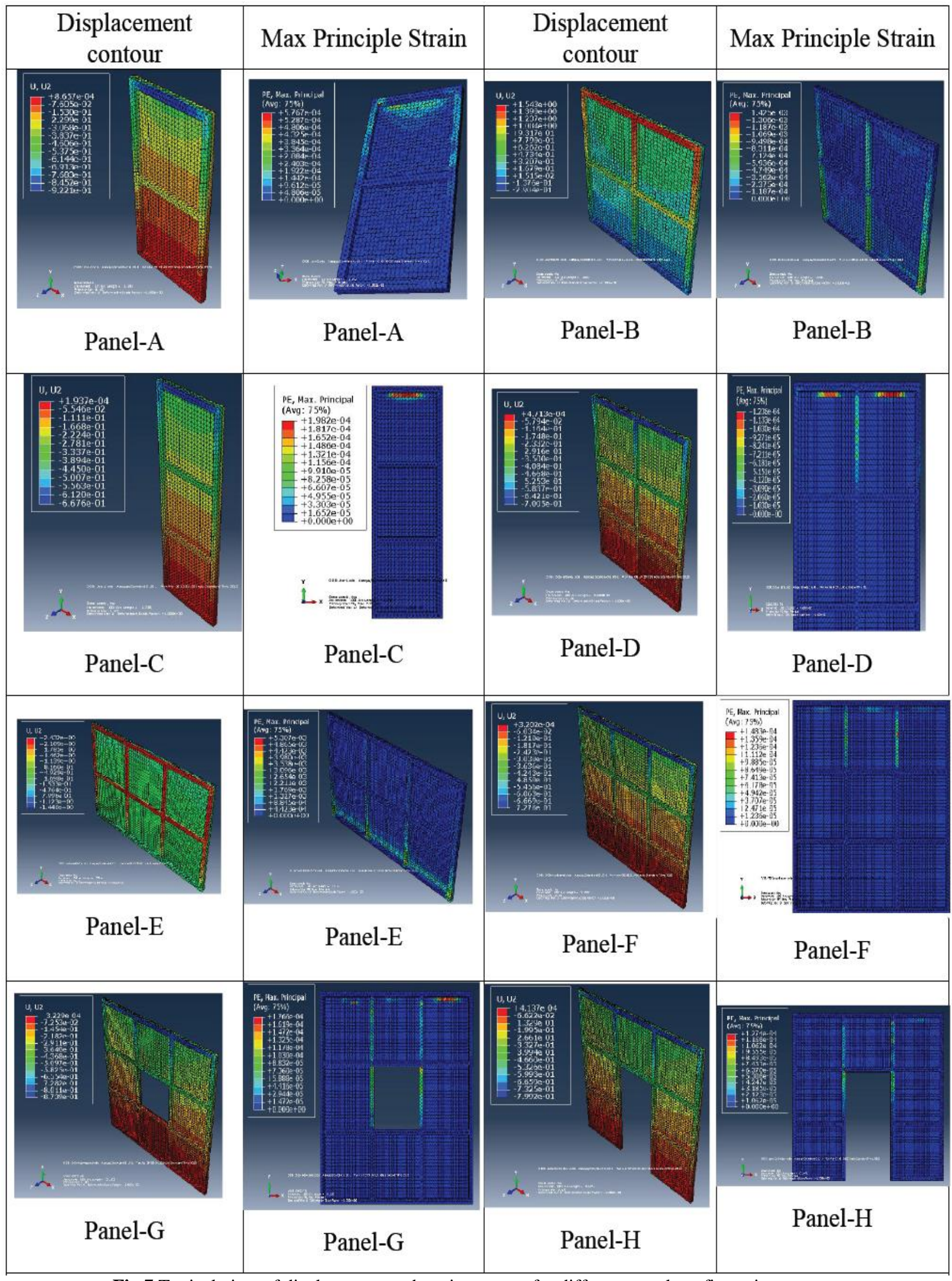

Fig 7 Typical view of displacement and strain contour for different panel configuration 


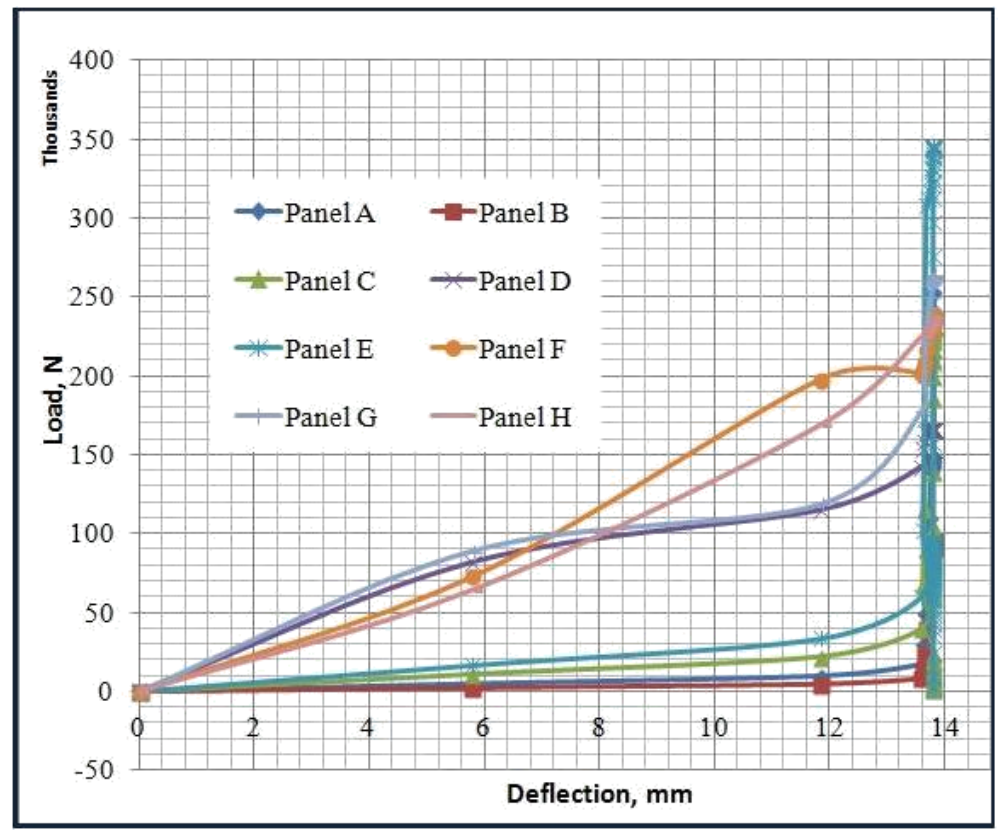

Fig 8 Load displacement curves of various panels (Numerical)
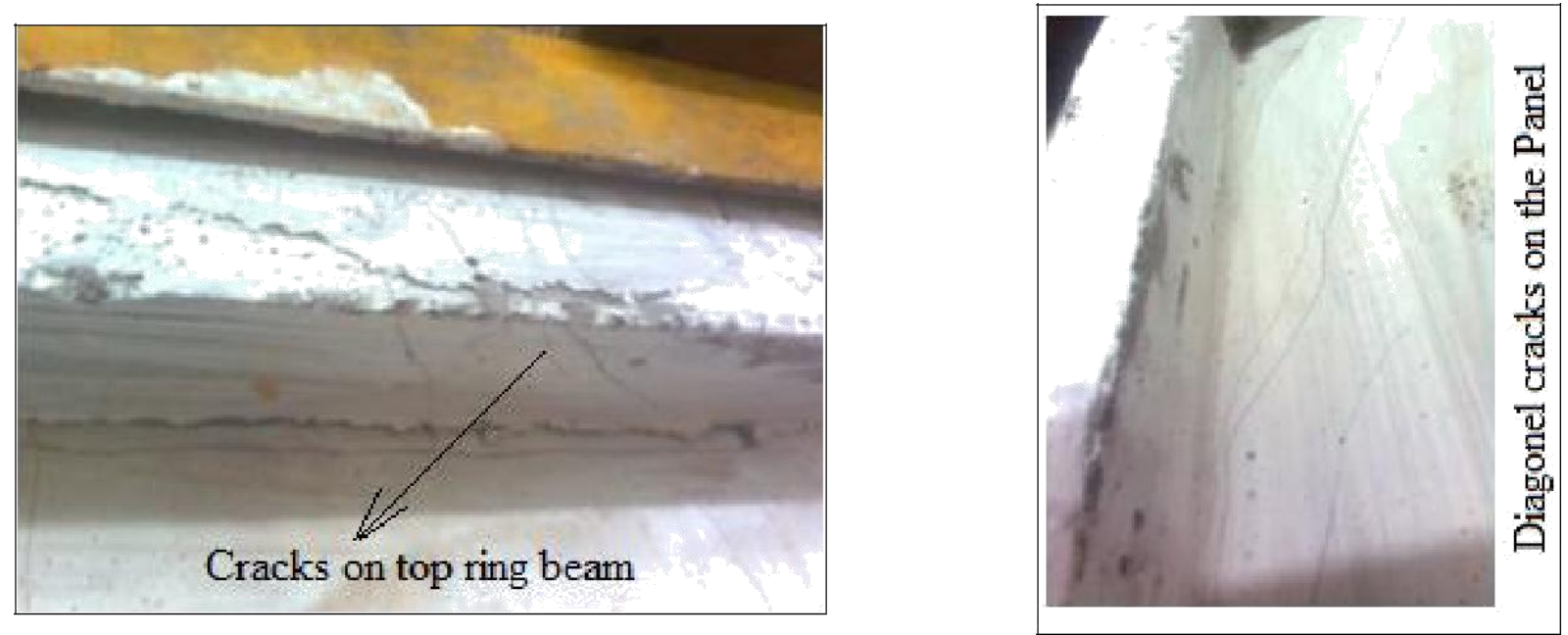

Fig 9 Typical view of Cracks on the rib and ferrocement panel

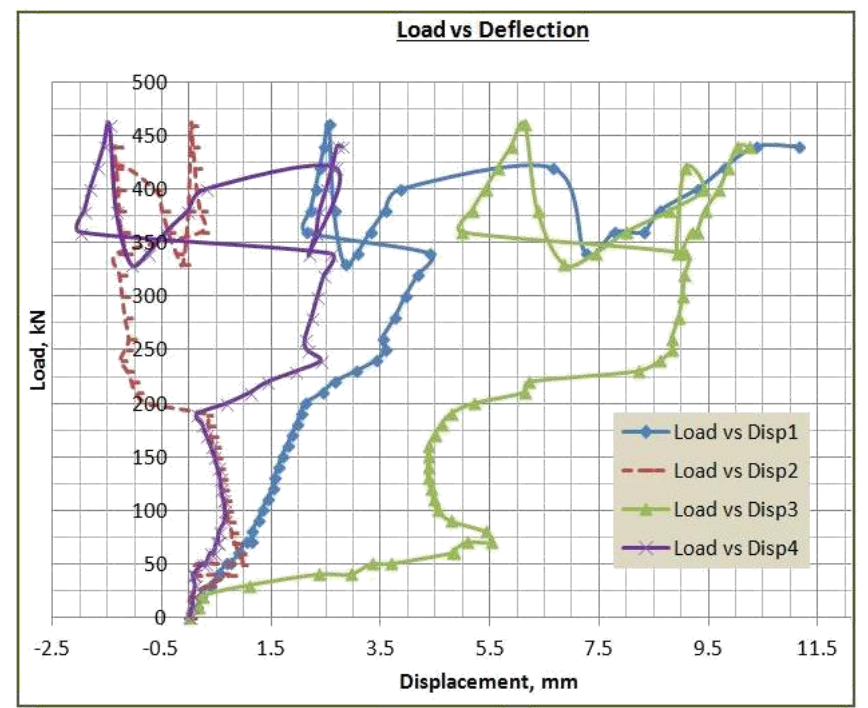

Fig 10 Load deflection behaviour of ferrocement wall panel 


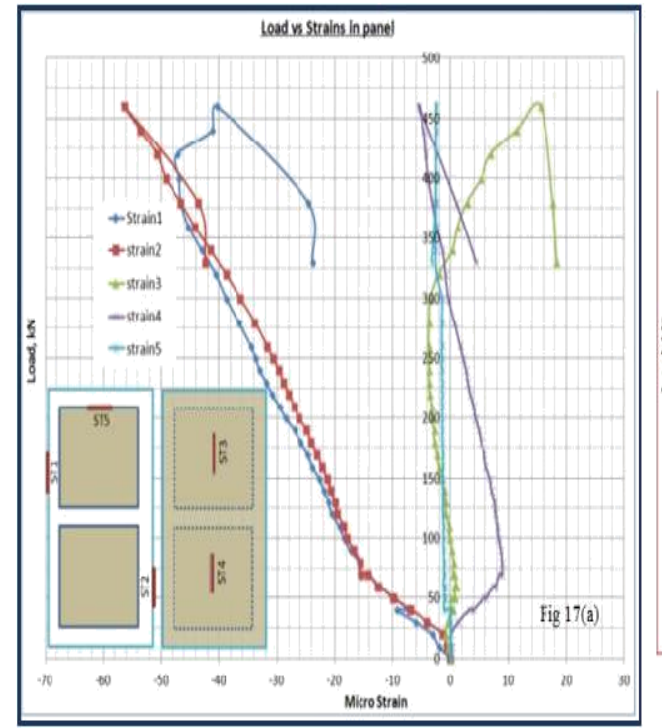

(a)

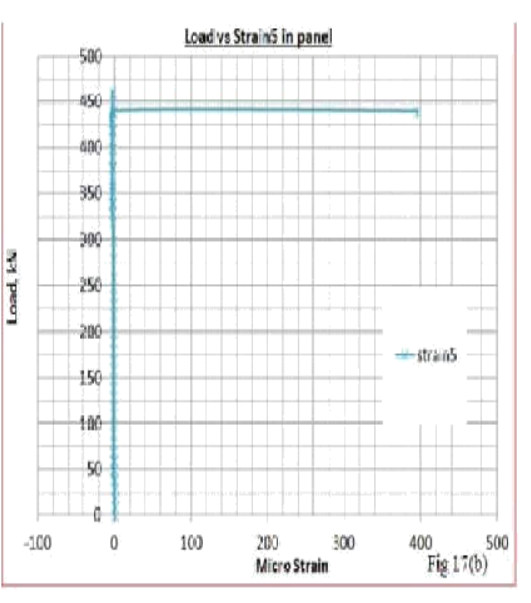

(b)

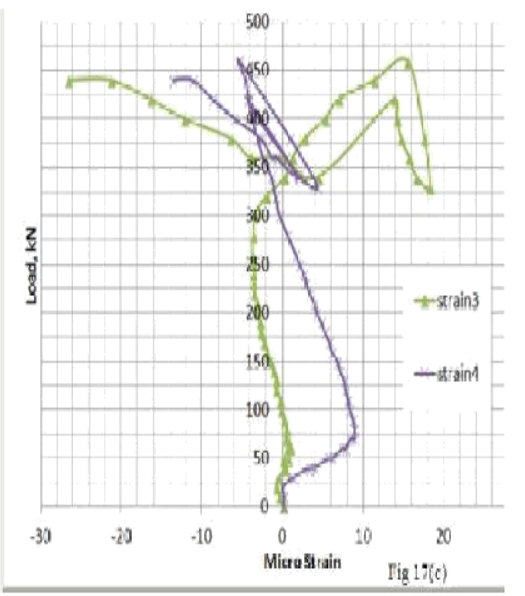

(c)

Fig 11 Comparison of load and strain at various location of wall panel

Table1 Mechanical Properties of SCM

\begin{tabular}{|l|c|c|c|c|}
\hline Specimen type & Cube & Cylinder & Cylinder & Prism \\
\hline $\begin{array}{l}\text { Strength } \\
\text { parameter }\end{array}$ & $\begin{array}{c}\text { Cube } \\
\text { Compression }\end{array}$ & $\begin{array}{c}\text { Compressive } \\
\text { strength }\end{array}$ & $\begin{array}{c}\text { Split tensile } \\
\text { strength }\end{array}$ & $\begin{array}{c}\text { Flexural } \\
\text { strength }\end{array}$ \\
\hline Average Strength & $47.11 \mathrm{~N} / \mathrm{mm}^{2}$ & $37.54 \mathrm{~N} / \mathrm{mm}^{2}$ & $3.61 \mathrm{~N} / \mathrm{mm}^{2}$ & $5.97 \mathrm{~N} / \mathrm{mm}^{2}$ \\
\hline
\end{tabular}

Table 2 Trial Mix Proportion

\begin{tabular}{|c|c|c|c|c|c|c|c|}
\hline Details & TM-1 & TM-2 & TM-3 & TM-4 & TM-5 & TM-6 & TM-7 \\
\hline $\mathrm{C}(\mathrm{OPC})$ & 1 & 1 & 1 & 1 & 1 & 1 & 1 \\
\hline FA & 0.3125 & 0.25 & 0.3 & 0.3 & 0.25 & 0.3 & 0.3 \\
\hline F-Ag & 1.79 & 2 & 2 & 2 & 1 & 2 & 2 \\
\hline C-Ag & 1.66 & 0 & 0 & 0 & 0 & 0 & 0 \\
\hline $\mathrm{W} / \mathrm{C}$ & 0.4 & 0.35 & 0.33 & 0.35 & 0.25 & 0.35 & 0.39 \\
\hline SP & $1.20 \%$ & $1.25 \%$ & $0.80 \%$ & $1 \%$ & $0.75 \%$ & $1.13 \%$ & $1.00 \%$ \\
\hline Observation & S\&B & $\frac{\text { S\&B, SP }}{(\text { excess \%) }}$ & $\begin{array}{l}\text { no S\&B, } \\
\text { stiff mix }\end{array}$ & $\begin{array}{l}\text { no S\&B, } \\
\text { stiff mix }\end{array}$ & $\begin{array}{l}\text { no S\&B, } \\
\text { rich mix }\end{array}$ & no S\&B & no S\&B \\
\hline $\begin{array}{c}\text { Slump Cone } \\
\text { Test }\end{array}$ & $\begin{array}{l}612 \\
\mathrm{~mm}\end{array}$ & $780 \mathrm{~mm}$ & $500 \mathrm{~mm}$ & $550 \mathrm{~mm}$ & $700 \mathrm{~mm}$ & $575 \mathrm{~mm}$ & $700 \mathrm{~mm}$ \\
\hline $\begin{array}{c}\text { V- Funnel } \\
\text { Test }\end{array}$ & - & 4.23 & - & - & $7.15 \mathrm{sec}$ & - & $7.2 \mathrm{sec}$ \\
\hline $\begin{array}{c}\text { Report / } \\
\text { decision } \\
\text { taken }\end{array}$ & $\mathrm{R}$ & R & $\mathrm{R}$ & $\mathrm{R}$ & $\begin{array}{c}\text { Accepte } \\
\text { d } \\
\text { Partially }\end{array}$ & R & Accepted \\
\hline $\begin{array}{c}\text { Note / } \\
\text { Abbreviation }\end{array}$ & $\begin{array}{l}\mathrm{R}= \\
\mathrm{Ag}\end{array}$ & $\begin{array}{l}\text { ted, TM } \\
\text { e, C-Ag }\end{array}$ & $\begin{array}{l}\text { ail Mix } \\
\text { urse A }\end{array}$ & $\begin{array}{l}\mathrm{C}=\text { Cemer } \\
\text { regate, } \mathrm{S} \&\end{array}$ & $\begin{array}{l}\text { FA = Fly } \\
=\text { Segre }\end{array}$ & $\begin{array}{l}\text { Ash, F-A } \\
\text { tion and }\end{array}$ & $\begin{array}{l}\text { Fine } \\
\text { eeding }\end{array}$ \\
\hline
\end{tabular}


Table 3 Ultimate load capacity of various panels

\begin{tabular}{|c|c|c|c|c|c|c|c|c|c|}
\hline \multicolumn{2}{|c|}{ Panel id } & $\mathrm{A}$ & B & $\mathrm{C}$ & $\mathrm{D}$ & $\mathrm{E}$ & $\mathrm{F}$ & $\mathrm{G}$ & $\mathrm{H}$ \\
\hline Load, & \multirow{2}{*}{ Analytical } & 253 & 157 & 230 & 165 & 350 & 270 & 240 & 230 \\
\hline $\begin{array}{l}\text { Stress, } \\
\mathrm{N} / \mathrm{mm}^{2}\end{array}$ & & 4.22 & 2.62 & 1.91 & 1.38 & 1.94 & 1.5 & 1.33 & 1.28 \\
\hline $\begin{array}{c}\text { Load, } \\
\mathrm{kN}\end{array}$ & \multirow{2}{*}{ Experimental } & 460 & \multirow{3}{*}{\multicolumn{7}{|c|}{$\begin{array}{l}\text { Note: Percentage of difference between the analytical and } \\
\text { experimental result is } 45 \% \text {, which requires further } \\
\text { improvement in the model. Further the difference is may } \\
\text { due to the strength characteristic variation of concretes } \\
\text { due to its anisotropic material heterogeneity. }\end{array}$}} \\
\hline $\begin{array}{l}\text { Stress, } \\
\mathrm{N} / \mathrm{mm}^{2}\end{array}$ & & 7.67 & & & & & & & \\
\hline \multicolumn{2}{|c|}{$\%$ of Difference } & $45 \%$ & & & & & & & \\
\hline
\end{tabular}

Table 4 Weight Analysis of Panels

\begin{tabular}{|l|l|l|l|l|l|l|}
\hline Type of wall & Size & Thickness & $\begin{array}{l}\text { Volume } \\
\left(\mathrm{m}^{3}\right)\end{array}$ & $\begin{array}{l}\text { Density } \\
\left(\mathrm{kg} / \mathrm{m}^{3}\right)\end{array}$ & $\begin{array}{l}\text { Weight } \\
(\mathrm{kg})\end{array}$ & $\begin{array}{l}\text { Reduction } \\
\text { in weight } \\
(\%)\end{array}$ \\
\hline $\begin{array}{l}\text { Conventional } \\
\text { brick wall }\end{array}$ & $1 \mathrm{~m} \times 2 \mathrm{~m}$ & $230 \mathrm{~mm}$ & 0.46 & 1900 & 874 & - \\
\hline $\begin{array}{l}\text { Ferrocement } \\
\text { wall panel }\end{array}$ & $1 \mathrm{~m} \times 2 \mathrm{~m}$ & $\begin{array}{l}25 \mathrm{~mm} \\
\text { without } \\
\text { ribs }\end{array}$ & 0.05 & 2200 & 110 & 87.414 \\
\hline $\begin{array}{l}\text { Ferrocement } \\
\text { wall panel }\end{array}$ & $1 \mathrm{~m} \times 2 \mathrm{~m}$ & $\begin{array}{l}25 \mathrm{~mm} \\
\text { with ribs }\end{array}$ & 0.0745625 & 2200 & 164.0375 & 81.2314 \\
\hline
\end{tabular}

